\title{
Consumer Behavior During the Christmas Season
}

\author{
Melissa M.F Waturandang ${ }^{1}$, Mercy Waney ${ }^{2}$, Yunita Sumakul ${ }^{3}$, Shanti Ruata ${ }^{4}$, \\ Aljuanika Ering ${ }^{5}$, Mariana Lausan ${ }^{6}$ \\ Institut Agama Kristen Negeri Manado \\ melissawaturandang@iakn-manado.ac.id¹, mercywaney79@gmail.com², yunita@iakn-manado.ac.id², \\ shantiruata@iakn-manado.ac.id ${ }^{4}$, aljuanikaering@iakn-manado.ac.id ${ }^{5}$, marianalausan@gmail.com ${ }^{6}$
}

\begin{abstract}
Christmas is a long-awaited holiday especially for Christians throughout the World, including the City of Manado where Manado City is one of the cities in Indonesia which has a majority Christian community. where the city of Manado is very enthusiastic where the shopping center is very crowded before Christmas. The purpose of this study is to find out how consumer behavior and what factors influence the decision making process of purchasing products before Christmas. From the results of data analysis it was found that psychological factors and social and cultural factors had the biggest role in the decision making process in purchasing consumer products, namely the Manado people before Christmas.
\end{abstract}

Keywords: Christmas, Consumer Behavior.

\section{Introduction}

Christmas for the majority of Christians in the World is an important and highly anticipated day, has a special meaning for Christians. Christmas from Portuguese which means "birth" is a Christian holiday that is celebrated annually by Christians on December 25 to commemorate the birthday of Jesus Christ. Christmas is celebrated at the evening service on December 24; and the morning service on December 25th. Some Orthodox churches celebrate Christmas on January 6. In the western tradition, Christmas commemoration also contains non-religious aspects. Some Christmas traditions originating from the West include Christmas trees, Christmas cards, exchanging gifts between friends and family members and stories about Santa Claus or Santa Claus.

Christmas is usually the biggest annual economic stimulus in various countries in the world. Sales of goods have increased sharply in various retail areas, and in the Christmas season people buy various Christmas gifts, decorations and supplies. Industries that depend on sales in the Christmas season include Christmas cards, Christmas trees, and others. In addition to the largest economic activity, Christmas Day in various Western countries is the quietest day for the business world; almost all retail stores, business and commercial institutions closed, and almost all industries stopped operating. Film studios release high-cost films in the Christmas season to entertain people, who are on vacation.

For the people of Manado, the majority are Christians based on Data from the Regional Office of the Ministry of Religion in North Sulawesi, namely Protestant Christians, which have the most followers with a percentage of 54.31 percent. Almost all Christians in Manado celebrate Christmas, For the People of Manado Christmas is a very special day. Not just a holiday, it is a day to gather with family and also a day where people enjoy all the work by doing or getting the things they dream of. 
Manado is one of the cities in Indonesia that celebrates Christmas with a festive celebration. Every corner of the city has Christmas knick knacks. When entering December, Christmas special songs start to sound, from supermarkets, minimarkets, radios, public transport speakers to mobile ringtones nuanced to Christmas songs. In addition to knick knacks and Christmas songs, residents from the countryside went down to the city of Manado to go shopping at the mall. The mall will look like a market and muddy, because it is filled with enthusiastic residents who shop.

The phenomenon of shopping in December or before Christmas becomes something very unique in the city of Manado, the shopping center is full and crowded with visitors who want to shop. Seen from the majority of residents of the city of Manado working as Civil Servants or Civil Servants, Teachers or Private Employees (41.44\%), as entrepreneurs (20.57\%), Traders $(12.85 \%)$, Farmers, Breeders, Fishermen $(9,17 \%)$, laborers $(8,96 \%)$ and the rest are engaged in the service sector and others (7\%). The North Sulawesi Province Minimum Wage is Rp. 3,051,076. certainly be interesting in examining how the behavior of consumers in the city of Manado ahead of Christmas, what factors are driving the Manado people in shopping near Christmas, remembering that most people are civil servants. What factors influence Consumer Behavior in this case the people of Manado in doing something especially the buying process ahead of the Christmas holiday. the purpose of this study is to analyze the factors that influence a person's behavior in shopping before the holiday especially inthe city of Manado

Consumer behavior is the process and activity when someone deals with the search, selection, purchase, use, and evaluation of products and services to meet the needs and desires (Duncan, Tom. 2005). The behavior of someone buying, being tempted to get certain items and spending money to get goods they like is one form of consumer behavior. Consumer behavior is not just a buying process but also a form of the process of getting something and its effect on yourself, how to buy not on the basis of basic needs but also the needs of selfactualization.

Factors that influence consumer behavior are external factors and individual internal factors. Psychological factors are internal and social environment are external factors. In Psychology, aspects that influence consumer behavior are perception, learning process, motivation, individual personality, attitudes and beliefs and self-concept (Mangkunegara, 2009). The study of consumer behavior studies the action or decision process in buying a product that is determined by economic, psychological and social cultural factors.

According to Mangkunegara (2002), factors that are quite influential in the consumer decision making process are:

a) Economic factors, related to the ability of consumers from the economic side to support the decision making process in buying

b) Psychological factors, related to learning experiences, personality, attitudes and beliefs, self-concept and individual motivation.

c) Socio-cultural factors, related to cultural factors and customs, social classes, role models and families.

There are five internal factors that are relevant to the purchasing decision making process (Duncan, Tom. 2005):

a) Motivation (motivation) is an impulse that exists in humans to achieve certain goals.

b) Perception (perception) is the result of a person's interpretation of the stimulus or event he received based on his information and experience of the stimulus.

c) Attitude formation is an assessment that is in someone who reflects the attitude of someone likes / dislikes about a thing. 
d) Integration (integration) is a union between attitude and action. Integration is a response to the attitude taken. Feelings like will encourage someone to buy and feelings of dislike will make a person's determination not to buy the product.

\section{Research Methods}

This study uses a qualitative method, a qualitative procedure using a phenomenological approach, data collection with open ended questionnaire to uncover what factors affect consumers in this case the people of Manado in making purchases before Christmas, as well as in-depth interviews and Focus Group Discussion (FGD) of 10 person.

Characteristics of Respondents are:

a) The people of Manado City and domiciled in the City of Manado

b) Christianity and Celebrate Christmas

c) Has income of 2 million - 5 million / month

\section{Result and Discussion}

The results showed that some respondents were in the consumptive type. Of the 10 respondents who on average have jobs as Civil Servants with an income of approximately 2-5 Million per month, spending carried out on the eve of Christmas cut almost $70 \%$ of the income earned, where the average purchase is for purchases fashion products, staples for Christmas food and drinks, home furnishings, home renovations and even buying new vehicles. From the open ended questionnaire, some responses felt that Christmas was the right time to shop.

Table 1. Product Purchased on Christmas

\begin{tabular}{cc}
\hline Product purchased & Amount \\
\hline Fashion Products & 10 \\
Food material & 10 \\
Home Furnishings & 4 \\
Building material & 3 \\
Vehicle & 1 \\
\hline
\end{tabular}

Factors that influence the purchase of products before Christmas are social cultural factors which for the sake of prestige or social status in society. Economic factors are not the main factor but quite influential seen from the answers of respondents who use excess funds, namely holiday allowances for shopping. Psychological factors also have a dominant influence in the purchase of clothes in the process of making decisions based on the motivation to be different, maximum to support self-confidence when celebrating Christmas. The prestige factor overcomes the functional factor where what is thought is for satisfaction in supporting one's status or prestige. 
Table 2. Reasons to shop on Christmas

\begin{tabular}{cc}
\hline Reasons & Amount \\
\hline Have more funds & 10 \\
Already a Tradition & 8 \\
Prestige & 9 \\
Want to be different & 10 \\
Satisfaction & 10 \\
\hline
\end{tabular}

The dominant reason underlying respondents when choosing a shopping product before Christmas is self-satisfaction where the motivation to look attractive is the main, the following factor is the Socio-cultural factor in making food product purchases where it has become a family tradition for generations by preparing typical food Christmas. This is directly related to tradition where the people of Manado believe that food is one way of uniting the family. at Christmas, besides gathering with the nuclear family, there is also an open house tradition where each family visits each other's family homes. Like the expression of a respondent below:

"Christmas all gather at home for Christmas special food, that food brings the family together."

For other respondents, renovating a house is a must do on Christmas because at Christmas, the house is the main place for family gatherings. In Manado, many people make the House as a meeting point for family gatherings for that new household furniture is important to add to the more festive atmosphere at Christmas. One example that is often revealed in interviews:

"Wow, the house is the most important, because there are all gathered, so the atmosphere of the house must be made pleasant for guests.

Christians in Manado celebrate Christmas by going to a place of worship, which is going to church, usually needing a vehicle if they decide to celebrate Christmas by returning to their home village or village. Therefore owning a car is one of the reasons for making purchases ahead of Christmas. Seen from the expression of one of the respondents:

"Christmas is usually accommodated so there must be a car to get there far away."

FGD results related to psychological dynamics that determine a person's behavior in the process of buying before Christmas is the stimulation of the environment associated with Christmas is a special day for all matters relating to daily life must be special starting with wearing new items, starting with products fashion, Christmas specialties that must exist and abound as part of tradition, home furnishings or home renovations in order to produce a pleasant atmosphere as well as new vehicles in addition to comfort as well as a symbol of success. Environmental influences or community groups and friends determine in the buying process ahead of Christmas. According to

Mangkunegara (2002), the influencing factors in the decision-making process of purchasing one of them is the Socio-Cultural Factor, where cultural and customs factors, social class, foster groups and families.

The results of the FGDs showed that most respondents were willing to spend the end of the month funds just before Christmas, for example by using holiday allowance money in accordance with the needs of the Christmas holiday. Respondents do not mind spending more money to shop before Christmas because for respondents it has become a habit and tradition.

"... well, use the THR money for Christmas, it's natural if you finish it all because it's Christmas, once a year it's a holiday, it's time to enjoy. " 
"I am not afraid of running out, right? The money can look for another moment that can not be missed, it is not a debauchery but it is tradition, it will feel different if you do not celebrate like a small time.

Celebrating Christmas to be like a moment to show social status, shop for new clothes, renovate the house and even buy a new vehicle is a natural thing to do on Christmas Day. The tendency towards personalization is to show a new lifestyle, desires are slightly different from others, all expressed through products or items purchased. What you buy and have shows who you are (Salomon, 2009), such as the statement of respondents, who shop before Christmas to desire to be different.

"Well, the name is also Christmas must be a new style, the end of the year so style."

"Change the car, so that later you will return to your village.

Respondents in this case as consumers have a tendency to highlight the status of a new symbol that is having material or is considered to have a lot of money (Mangkunegara, 2009). This factor defeats the need factor related to the function of the product, but the purchase occurs is inseparable from the psychological factors that influence namely personality, selfconcept and motivation.

\section{Conclusion}

The results of this study indicate that personal and psychological factors have an important role in the decision making process of buying or shopping on Christmas is influenced by several factors, many factors that are quite influential for the people of Manado, both individual and social factors. But all factors have a psychological influence on consumers. The people of Manado have a consumptive tendency that is influenced by the need for affirming their social status, lifestyle, this tendency is increasing in the time before Christmas, followed by the majority of the people of Manado are Christians. The people of Manado make Christmas a time to show their lifestyle, and on the Christmas day the people of Manado are the right time to spend year-end funds.

Social and cultural factors become quite influential factors in which the people of Manado in celebrating Christmas that is doing shopping is based on a tradition that has been passed down through generations, how to celebrate, starting from appearance, typical food that must be there, all adapted to existing family traditions. all oriented towards celebrating from community groups or families. Psychological factors have an important role for the people of Manado in making purchases before Christmas in the decision making process consumers usually have personal motivation for self-satisfaction.

Based on the results of this study, it can be suggested that the next researcher uses quantitative and experimental methods to be able to see the whole with a larger and more comprehensive scale.

\section{References}

[1] Badan Pusat Statistik, Jakarta, 2019

[2] Duncan, Tom. 2005. Principles of Advertising \& IMC, Second Edition. McGraw-Hill, Inc

[3] Gerald Zaltman and Melanie Wallendorf. 1971. Cunsumer Behavior ; Basic Findings and Management Implication. USA. John Wiley \& Sons Inc. 
[4] Mangkunegara, Anwar Prabu. 2002. Perilaku Konsumen. Bandung. Refika Aditama.

[5] Manado.tribunnews.com/2018/12/02/natal-orangmanado

[6] Restad, Penne L. (1995). Christmas in America: A History. New York: Oxford University Press.ISBN0-19-509300. 